\title{
Role of Chronic Inflammation and Resulting DNA Damage in Cervical Carcinogenesis Induced by Human Papillomavirus
}

\author{
Yusuke Hiraku \\ Department of Environmental and Molecular Medicine, \\ Mie University Graduate School of Medicine
}

Japan

\section{Introduction}

Cervical cancer is the second most common cancer among women in the worldwide. Especially, in many regions of developing countries, cervical cancer is the most common among women. Infection with human papillomavirus (HPV) is a necessary event preceding the development of premalignant lesions in the cervical epithelium, which can partially progress to cancer. HPV DNA can be identified in almost all specimens of patients with invasive cervical cancer (Chen \& Hunter, 2005; Munoz et al., 2003; Tindle, 2002). Molecular epidemiological studies have demonstrated that specific subtypes of HPV are closely associated with cervical cancer, although the risk of cervical cancer varies with HPV types (Bosch et al., 2002; Chen \& Hunter, 2005; International Agency for Research on Cancer [IARC] Working Group, 2007; 2011; Munoz et al., 2003; Sisk \& Robertson, 2002; Tindle, 2002). IARC has classified several types of high-risk HPV, including HPV-16 and HPV-18, to be carcinogenic to humans (group 1) (IARC Working Group, 2007; 2011).

The molecular mechanisms of HPV-induced carcinogenesis have been extensively investigated by focusing on HPV oncoproteins, E6 and E7 (Yugawa \& Kiyono, 2009). E6 and E7 genes are invariably expressed in HPV-positive cervical cancer cells. E6 protein forms a ubiquitin ligase complex with E6-associated protein (E6AP) and promotes the degradation of p53 protein, a tumor suppressor gene product involved in apoptosis, cell cycle arrest and DNA repair. The E6/E6AP complex also induces the transcription of the catalytic subunit of human telomerase reverse transcriptase (hTERT) via degradation of the repressor NFX1-91, leading to cell immortalization (Xu et al., 2008). E7 oncoprotein binds and degrades retinoblastoma protein (RB), a major negative regulator of the cell cycle, and the related family members (Duensing \& Munger, 2004). Recent studies demonstrated that E7-mediated degradation of RB requires the calcium-activated calpain, a cysteine protease (Darnell et al., 2007) and involves the interaction with p600, an RB- 
associated factor (Huh et al., 2005). E7 also inactivates the cyclin-dependent kinase (CDK) inhibitors, p21 and p27 (Duensing \& Munger, 2004). E7-induced RB degradation leads to the release of the transcription factor $\mathrm{E} 2 \mathrm{~F}$ from the $\mathrm{RB} / \mathrm{E} 2 \mathrm{~F}$ transcriptional repressor complex (von Knebel Doeberitz, 2002). Activation of E2F mediates gene transcription with increased expression of cyclin E and cyclin A and aberrant CDK2 activity (Duensing \& Munger, 2004). In addition, these oncoproteins cause genomic instability (Duensing \& Munger, 2004). E6 and E7 cooperatively induce numerical centrosome aberrations and eventual aneuploidy in cells overexpressing these oncoproteins (Duensing et al., 2000). E7 protein of high-risk type HPV induced chromosome overduplication associated with aberrant multipolar spindle pole formation, while E6 had no immediate effects on centrosome numbers but potentiated mitotic disturbance (Duensing et al., 2000). On the basis of these numerous studies, E6 and E7 oncoproteins are considered to participate in cervical carcinogenesis by inducing cell immortalization, dysregulation of cell proliferation and chromosomal instability.

However, it has been reported that these oncoproteins are insufficient to transform human cells, and additional cellular events are required for cervical carcinogenesis (Duensing \& Munger, 2004). The activation of Ha-ras in HPV16-immortalized human cervical cells resulted in malignancy, while transfection of HPV-16 DNA alone into cervical cells did not (DiPaolo et al., 1989). Human protooncogenes, including the c-Ha-ras gene, can be activated via oxygen radical-induced DNA damage (Du et al., 1994). HPV oncoprotein-expressing cells have an impaired ability to respond to DNA damage (Kessis et al., 1993; Song et al., 1998). These findings raise the possibility that additional factors other than HPV infection mediate DNA damage and participate in carcinogenesis. Recent epidemiological and experimental studies have demonstrated that chronic inflammation contributes to cervical carcinogenesis as described in the following section. In this review, the role of inflammation and resulting DNA damage in cervical carcinogenesis and the molecular mechanisms will be discussed.

\section{Involvement of chronic inflammation in cervical carcinogenesis}

In 19th century, Rudolf Virchow noted leucocytes in neoplastic tissues and suggested that the "lymphoreticular infiltrate" reflected the origin of cancer at sites of chronic inflammation (Balkwill \& Mantovani, 2001). Since then, there has been a growing research interest in the link between chronic inflammation and carcinogenesis. Actually, many malignancies arise from areas of infection and inflammation (Balkwill \& Mantovani, 2001; Coussens \& Werb, 2002). Epidemiological and experimental studies have provided evidence indicating that chronic infection and inflammatory conditions contribute to a substantial part of environmental carcinogenesis (Coussens \& Werb, 2002; IARC, 2003). A recent review has estimated that chronic inflammation accounts for approximately $25 \%$ of human cancers (S. P. Hussain \& Harris, 2007). Infection with bacteria, viruses and parasites contributes to a substantial part of chronic inflammation. IARC has estimated that infectious diseases account for approximately $18 \%$ of cancer cases worldwide, which are largely attributed to infection with oncogenic viruses, including HPV (IARC, 2003) (Table 1). Cervical cancer mediated by HPV accounts for approximately $6 \%$ of cancer cases, and the largest part of infection-related carcinogenesis. 


\begin{tabular}{|c|c|c|c|}
\hline Infectious agents* & Cancer site & $\begin{array}{l}\text { Number of } \\
\text { cancer cases }\end{array}$ & $\begin{array}{c}\% \text { of cancer } \\
\text { cases } \\
\text { worldwide }\end{array}$ \\
\hline \multicolumn{4}{|c|}{ Bacterial infection } \\
\hline Helicobacter pylori & Stomach & 490,000 & 5.4 \\
\hline \multicolumn{4}{|c|}{ Viral infection } \\
\hline $\begin{array}{l}\text { Human papillomavirus (HPV) } \\
\text { (especially high-risk types) }\end{array}$ & Cervix and other sites & 550,000 & 6.1 \\
\hline $\begin{array}{l}\text { Hepatitis B virus } \\
\text { Hepatitis C virus } \\
\end{array}$ & Liver & 390,000 & 4.3 \\
\hline Epstein-Barr virus (EBV) & Lymphoma and nasopharynx & 99,000 & 1.1 \\
\hline $\begin{array}{c}\text { Human T-cell lymphotropic } \\
\text { virus (HTLV-1) }\end{array}$ & Leukemia & 9,000 & 0.1 \\
\hline \multicolumn{4}{|c|}{ Parasitic infection } \\
\hline Schistosoma haematobium & Bladder & 2,700 & 0.1 \\
\hline \multirow[t]{2}{*}{$\begin{array}{c}\text { Opisthorchis viverrini } \\
\text { (Liver fluke) }\end{array}$} & Intra- and extrahepatic bile duct & 800 & \\
\hline & $\begin{array}{c}\text { Total infection-related cancers } \\
\text { Total cancers in } 1995\end{array}$ & $\begin{array}{l}1,600,000 \\
9,000,000\end{array}$ & $\begin{array}{l}17.7 \\
100\end{array}$ \\
\hline
\end{tabular}

*The pathogens listed here have been evaluated as group 1 carcinogens (carcinogenic to humans) by IARC.

Table 1. Burden of infection-related cancer worldwide [Adapted and modified from (IARC, 2003)]

\subsection{Epidemiological studies on chronic inflammation and cervical carcinogenesis}

Recent epidemiological and experimental studies have revealed that chronic inflammation is associated with HPV-induced cervical carcinogenesis, although it is still unclear whether HPV infection alone or co-infection with HPV and other pathogens induces inflammatory conditions. An epidemiological study in Costa Rica revealed that there was a positive trend of increasing cervical inflammation associated with high-grade lesions in oncogenic HPVinfected women, and proposed a possibility that cervical inflammation is a cofactor for HPV-induced carcinogenesis (Castle \& Giuliano, 2003; Castle et al., 2001). Several epidemiological studies have suggested that other pathogens act in conjunction with HPV infection to increase the risk of cervical cancer. Chlamydia trachomatis infection increased the risk of squamous cervical cancer among HPV-positive women in Brazil and the Philippines (Smith et al., 2002b). Among the HPV DNA-positive women, seropositivity of herpes simplex virus-2 was associated with increased risks of squamous-cell carcinoma and adenoor adenosquamous-cell carcinoma (Smith et al., 2002a). In a study using cervical smears, the relative risk of high grade squamous intraepithelial lesions was significantly higher in patients infected with Gardinerella vaginalis and Chramydia and with dysbacteriosis and nonspecific inflammatory changes (leucocytosis) compared with normal subjects (Roeters et al., 2010). In addition, there is a study showing that biopsy specimens of women infected with carcinogenic HPV type had greater inflammation in the epithelium compared with those of women positive for noncarcinogenic HPV type and negative for HPV, although cervical inflammation varies with HPV cofactors, type of HPV infection, and risk of persistence and 
progression (Kovacic et al., 2008). Recently, meta-analysis showed that bacterial vaginosis is significantly and positively associated with cervical HPV infection (Gillet, et al., 2011), supporting the hypothesis that cervical inflammation is involved in the pathogenesis of HPV-induced cancer.

\subsection{Molecular epidemiological studies on cervical carcinogenesis}

The expression of inflammation-related molecules in cervical tissues and the association with HPV-induced carcinogenesis have been extensively investigated. Activation of the transcription factor nuclear factor $(\mathrm{NF})-\mathrm{\kappa} B$ has been observed in cervical tissues of patients with squamous intraepithelial lesions. In normal cervical tissue and low-grade squamous

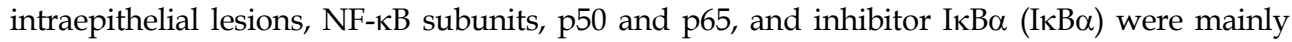
localized in the cytosol, whereas in high-grade lesions and squamous cell carcinomas, the p50p65 heterodimer was translocated into the nucleus and the expression of I $\mathrm{BB} \alpha$ protein was concurrently decreased (A. Nair et al., 2003). NF- $\mathrm{kB}$ is a key player in inflammation and regulates the expression of various genes involved in controlling the inflammatory response, including inducible nitric oxide synthase (iNOS), cyclooxygenase-2 (COX-2), interleukin (IL)$1 \beta$ and tumor necrosis factor (TNF)- $\alpha$ (Karin, 2006; Kundu \& Surh, 2008). NF- $\kappa$ B also participates in the promotion and progression of inflammation-related cancer (Karin, 2006; Pikarsky et al., 2004). NF-кB mediates the expression of matrix metalloprotease (MMP) 9 and the angiogenic factor, vascular endothelial growth factor (VEGF) (Karin, 2006), which are considered to participate in tumor progression and metastasis.

COX-2 mediates cancer development via various pathogenic events, including inflammatory responses, apoptosis inhibition and angiogenesis (Chun \& Surh, 2004; Warner \& Mitchell, 2004; Williams et al., 2000). Molecular epidemiological studies have shown the overexpression of COX-2 in cervical cancer (Kim et al., 2004; Kulkarni et al., 2001). Patients positive for both COX-2 and epidermal growth factor receptor (EGFR) had a higher likelihood of locoregional recurrence and worse prognosis than those negative for one or both proteins (Kim et al., 2004).

In biopsy specimens of cervical intraepithelial neoplasia (CIN) 3 patients, activation of signal transducer and activator of transcription (STAT) 3 and coexpression of MMP9 have been detected in perivascular inflammatory cells. STAT3 induced the expression of the chemokine CCL2, followed by MMP9 expression in tumor-instructed monocytes (Schroer et al., 2011). Recently, it has been reported that the plasma levels of cytokines, especially IL-6, IL-8, TNF- $\alpha$ and macrophage inflammatory protein- $\alpha$ (MIP-1 $\alpha)$, were significantly increased in HPV-positive women relative to HPV-negative controls (Kemp et al., 2010). Therefore, the evidence for the participation of inflammatory responses in cervical carcinogenesis has been accumulating, although further studies are required to clarify the precise molecular mechanism.

\section{DNA damage mediated by reactive species under inflammatory conditions}

DNA damage is a key molecular event causing genetic instability involved in induction of human carcinogenesis. Under inflammatory conditions, reactive oxygen species (ROS) and reactive nitrogen species (RNS), including nitric oxide (NO), are generated from inflammatory and epithelial cells. These species are highly reactive and capable of causing oxidative and nitrative DNA damage, which may contribute to carcinogenesis (S. P. Hussain 
et al., 2003; J. Nair et al., 2006; Ohshima et al., 2003). ROS can induce the formation of various oxidative DNA lesions, including mutagenic 8-oxo-7,8-dihydro-2'-deoxyguanosine (8-oxodG) (Kawanishi et al., 2001; Tazawa et al., 2003; Wiseman \& Halliwell, 1996). If 8oxodG is not correctly repaired, adenine is preferentially incorporated opposite 8-oxodG during DNA synthesis, leading to $\mathrm{G} \rightarrow \mathrm{T}$ transversion (David et al., 2007; Shibutani et al., 1991). Accumulation of 8-oxodG in human body has been demonstrated in patients with cancer and cancer-prone diseases. A significant increase in urinary 8-oxodG levels has been observed in patients with various types of cancer compared with those in control subjects (Erhola et al., 1997; Tagesson et al., 1995; Thanan et al., 2008). The content of 8-oxodG in cervical cells significantly increased with the grade of squamous intraepithelial lesion (Romano et al., 2000), raising the possibility that oxidative DNA damage participates in cervical carcinogenesis.

Whereas ROS are generated from multiple sources, including not only inflammatory cells but also carcinogenic chemicals and electron transport chain in mitochondria, RNS are primarily generated under inflammatory conditions (Kawanishi \& Hiraku, 2006). Therefore, RNS-mediated DNA lesions may play an important role in inflammation-related carcinogenesis, and are expected as potential biomarkers to evaluate the cancer risk. 8Nitroguanine is a nitrative DNA lesion, formed under inflammatory conditions. NO and superoxide $\left(\mathrm{O}_{2}{ }^{-}\right)$are generated from inflammatory and epithelial cells, and react with each other to form peroxynitrite (ONOO-), a highly reactive species causing nitrative and oxidative DNA damage. In vitro experiments revealed that the interaction of guanine with ONOO- led to the formation of 8-nitroguanine (Yermilov et al., 1995a), in addition to 8oxodG (Inoue \& Kawanishi, 1995) (Figure 1). In an in vivo experiment, 8-nitroguanine was formed via inflammation in the lung tissues of mice with viral pneumonia (Akaike et al., 2003).

8-Nitroguanine formed in DNA is chemically unstable, and can be spontaneously released, resulting in the formation of an apurinic site (Yermilov et al., 1995b). Adenine is preferentially incorporated opposite an apurinic site during DNA synthesis, leading to $G \rightarrow$ T transversion (Loeb \& Preston, 1986). Translesion DNA synthesis is the process in which error-prone DNA polymerases bypass unrepaired DNA lesions or insert nucleotides opposite the lesions. Cells deficient in subunits of DNA polymerase $\zeta$, were hypersensitive to NO, and translesion DNA synthesis past apurinic site mediated by this polymerase might contribute to extensive point mutations (Wu et al., 2006). It has also been reported that adenine is preferentially incorporated opposite 8-nitroguanine during DNA synthesis mediated by DNA polymerase $\eta$ and $\kappa$, leading to $G \rightarrow T$ transversion (Suzuki et al., 2005). Therefore, 8-nitroguanine is a potentially mutagenic DNA lesion, which may contribute to inflammation-related carcinogenesis. In the ONOO-treated supF shuttle vector plasmid, which was then replicated in Escherichia coli, the majority of mutations occurred at G:C base pairs, predominantly involving $\mathrm{G} \rightarrow \mathrm{T}$ transversions (Juedes \& Wogan, 1996; M.Y. Kim et al., 2005). Indeed, this type of mutation occurred in vivo in the ras gene (Bos, 1988) and the p53 tumor suppressor gene in lung and liver cancer (Hsu et al., 1991; Takahashi et al., 1989). $\mathrm{G} \rightarrow \mathrm{T}$ transversions were most prominently detected in the omentum of asbestos-exposed rats (Unfried et al., 2002). These findings imply that DNA damage mediated by inflammatory reactions may participate in carcinogenesis via activation of protooncogenes and inactivation of tumor suppressor genes. 


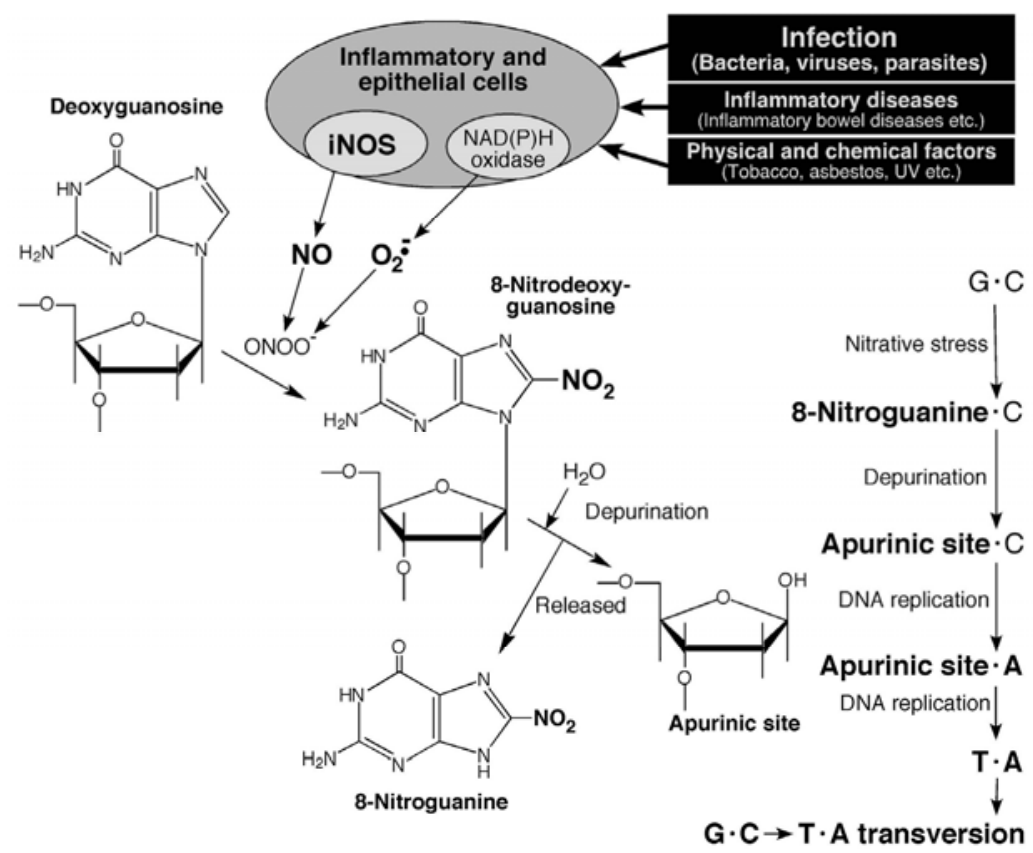

Fig. 1. Proposed mechanism of 8-nitroguanine formation and mutation under inflammatory conditions.

\section{Nitrative DNA damage during cervical carcinogenesis}

\subsection{DNA damage in cervical tissues of CIN patients}

To clarify the role of inflammation-mediated DNA damage in cervical carcinogenesis, we performed immunofluorescence staining to examine the formation of 8-nitroguanine and 8oxodG in biopsy specimens obtained from CIN patients. To detect 8-nitroguanine, we produced a specific antibody and used for experiments (Hiraku \& Kawanishi, 2009; Pinlaor et al., 2004a). We compared the fluorescent intensity of these DNA lesions in cervical tissues of patients with different stages of CIN caused by high-risk HPV and condyloma acuminatum, benign cervical warts caused by low-risk HPV. In biopsy specimens of CIN patients, 8-nitroguanine formation was observed in the nuclei of atypical cells (Figure 2), and 8-oxodG showed a similar staining pattern to 8-nitroguanine. Their staining intensity tended to increase with CIN grades. Statistical analysis revealed that the immunoreactivity of 8-nitroguanine in cervical epithelium was significantly increased in the order of condyloma acuminatum < CIN1 < CIN2-3, while there was no significant difference in 8oxodG formation (Table 2). iNOS expression was also observed in the cytoplasm of both cervical epithelial cells and infiltrating stromal inflammatory cells in CIN patients. 8Nitroguanine formation was observed in the majority of iNOS-positive epithelial cells. On the other hand, no or weak 8-nitroguanine formation occurred in cervical tissues from patients with condyloma acuminatum. These results raise the possibility that 8 -nitroguanine can be used a potential biomarker to evaluate the risk of cervical carcinogenesis. 

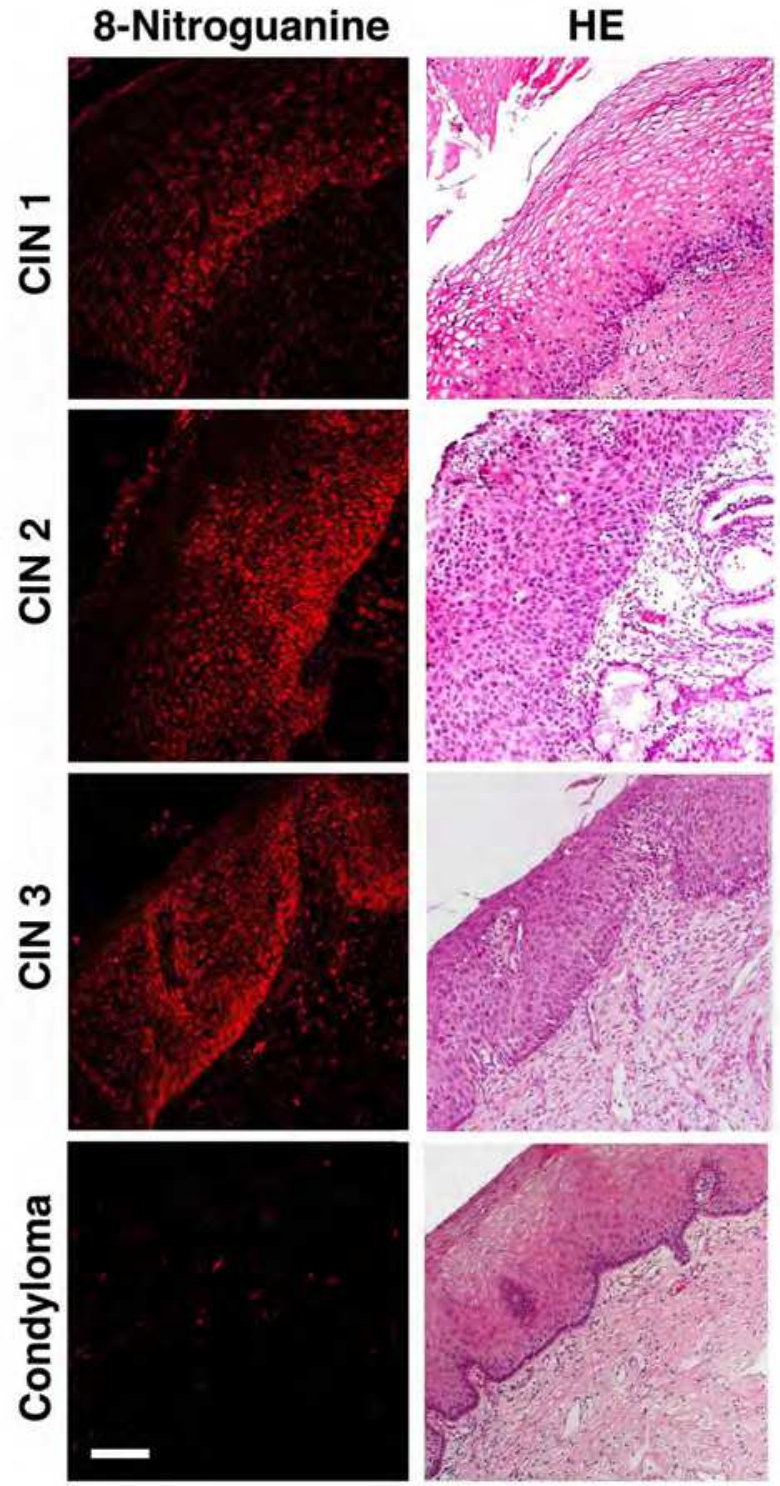

Fig. 2. 8-Nitroguanine formation and histopathological changes in cervical biopsy specimens. 8-Nitroguanine formation was assessed by immunofluorescence staining, and histopathological changes were examined by hematoxylin and eosin (HE) stain. Paraffin sections were incubated with the primary antibody (rabbit polyclonal anti-8-nitroguanine antibody) and then with the secondary antibody (Alexa 594-labeled goat anti-rabbit IgG antibody). 8-Nitroguanine formation was observed in the nuclei of atypical epithelial cells. In the patients with condyloma acuminatum, no or weak 8-nitroguanine formation occurred. Scale bar $=50 \mu \mathrm{m}$. 


\begin{tabular}{|c|c|c|c|c|}
\hline \multirow[b]{2}{*}{ Biomarkers } & \multirow{2}{*}{$\begin{array}{l}\text { Immunoreactivity } \\
\text { Grading* }\end{array}$} & \multicolumn{3}{|c|}{ Number of cases } \\
\hline & & $\begin{array}{l}\text { Condyloma } \\
\quad(\mathrm{n}=5)\end{array}$ & $\begin{array}{l}\text { CIN1 } \\
(\mathrm{n}=9)\end{array}$ & $\begin{array}{l}\text { CIN2-3 } \\
(n=16)\end{array}$ \\
\hline \multirow{4}{*}{ 8-Nitroguanine } & - & 4 & 4 & 2 \\
\hline & + & 1 & 2 & 7 \\
\hline & ++ & 0 & 3 & 4 \\
\hline & +++ & 0 & 0 & 3 \\
\hline \multirow{4}{*}{$P$} & Kruskal-Wallis** & & $0.024^{\#}$ & \\
\hline & \multirow{3}{*}{ Scheffe } & \multicolumn{2}{|c|}{0.396} & \\
\hline & & \multicolumn{3}{|c|}{$0.030^{\#}$} \\
\hline & & & & \\
\hline \multirow{4}{*}{ 8-oxodG } & - & 4 & 4 & 7 \\
\hline & + & 1 & 4 & 3 \\
\hline & ++ & 0 & 1 & 3 \\
\hline & +++ & 0 & 0 & 3 \\
\hline$P$ & Kruskal-Wallis & & 0.232 & \\
\hline \multirow{4}{*}{ p16 } & - & 1 & 1 & 2 \\
\hline & + & 3 & 6 & 5 \\
\hline & ++ & 1 & 1 & 8 \\
\hline & +++ & 0 & 1 & 1 \\
\hline$P$ & Kruskal-Wallis & \multicolumn{3}{|c|}{0.332} \\
\hline
\end{tabular}

*The immunoreactivity for each specimen was scored as follows: $(-)$ no or few cells were positive, $(+)$ $>25 \%$ of the cells were positive, $(++)>50 \%$ of the cells were moderately positive, and $(+++)>75 \%$ of the cells were strongly positive.

**The statistical difference in immunoreactivities was analyzed by Kruskal-Wallis test, and if there was a statistical significance, Scheffe's multiple comparison was performed. $\# P<0.05$.

Table 2. Difference in immunoreactivies of DNA lesions and p16 in cervical epithelial cells of biopsy specimens obtained from patients with CIN and condyloma acuminatum

The formation of nitrative DNA lesion in relation to cervical carcinogenesis has been supported by a recent study. NO exposure induced DNA damage and increased mutation rates in HPV-positive human cervical epithelial cell lines established from CIN patients (Wei et al., 2009). In addition, NO exposure increased the expression of E6 and E7 genes, resulting in decreased p53 and RB protein levels in these cells (Wei et al., 2009), although precise molecular mechanism has not been understood. These findings raise the possibility that NO serves as a molecular cofactor with HPV infection, and resulting DNA damage and the expression of viral oncoproteins cooperatively contribute to HPV-mediated cervical carcinogenesis. Therefore, modification of local NO concentration in cervical tissues and related molecular events may constitute a strategy to prevent HPV-related cancer. 


\subsection{Comparison of 8-nitroguanine formation and p16 expression in CIN patients}

There are several reports showing that the cyclin-dependent kinase inhibitor p16 is overexpressed in cervical neoplasia (Gupta et al., 2010; Klaes et al., 2001; Sano et al., 1998; von Knebel Doeberitz, 2002; J. L. Wang et al., 2004), and proposed as a potential biomarker of cervical carcinogenesis. The expression of p16 was significantly higher in CIN and squamous cell cancer than in normal or inflammation of the cervix, and p16-positive patients had significantly shorter interval for disease progression from initial biopsy to CIN 3 or invasive cancer than p16-negative patients (J. L. Wang et al., 2004). E7 oncoprotein binds to RB, leading to the release of the transcription factor E2F from the RB/E2F complex (von Knebel Doeberitz, 2002). E2F accumulation leads to the expression of p16-related transcript, although the molecular mechanism remains to be clarified (Khleif et al., 1996).
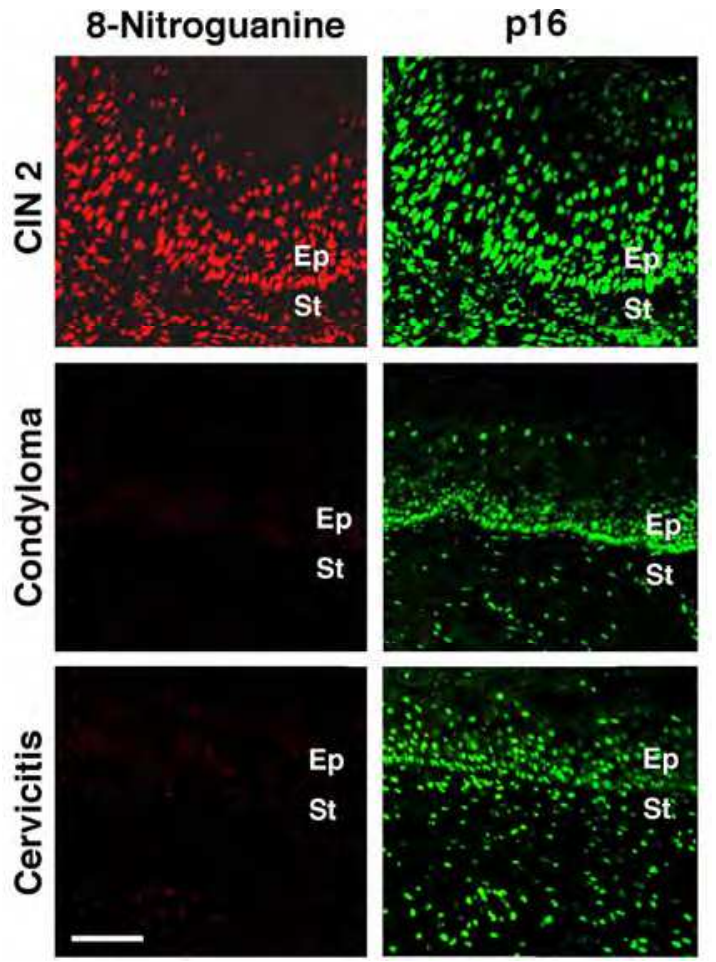

Fig. 3. 8-Nitroguanine formation and p16 expression in cervical biopsy specimens. 8-

Nitroguanine formation and p16 expression were assessed by immunofluorescence staining. Paraffin sections were incubated with the primary antibodies (rabbit polyclonal anti-8nitroguanine and mouse monoclonal anti-p16 antibodies), and then with the secondary antibodies (Alexa 594-labeled goat anti-rabbit IgG and Alexa 488-labeled goat anti-mouse IgG antibodies). Strong p16 expression (green) was observed in cervical epithelial cells of CIN2 patients and showed a similar pattern to 8-nitroguanine formation (red). In patients with condyloma acuminatum and cervicitis (HPV-16-positive), p16 expression was observed in the basal layer but no or weak 8-nitroguanine formation was detected. Ep, epithelium. St, stroma. Scale bar $=50 \mu \mathrm{m}$. 
We performed immunohistochemistry to compare 8-nitroguanine formation and p16 expression in cervical biopsy specimens of HPV-infected patients. Strong p16 expression was observed in cervical epithelial cells of CIN patients and showed a similar pattern to 8nitroguanine (Figure 3). However, in cervical tissues of patients with condyloma acuminatum and HPV-positive cervicitis, p16 expression was observed in the basal layer, whereas no or weak 8-nitroguanine formation was detected. Statistical analysis revealed that no significant difference in p16 expression was observed among condyloma and CIN groups, whereas there was significant difference in 8-nitroguanine formation as described above (Table 2). These results suggest that p16 is simply a marker to reflect HPV infection, and that 8-nitroguanine is more suitable marker to discriminate high-risk and low-risk cervical lesions.

\section{Role of nitrative DNA damage in inflammation-related carcinogenesis}

\subsection{8-Nitroguanine formation in inflammation-related carcinogenesis}

In addition to cervical cancer, we have investigated 8-nitroguanine formation in tissues of patients and animal models of a wide variety of inflammation-related cancer and cancerprone diseases by immunohistochemical analysis. We first demonstrated that this DNA lesion was formed at the site of carcinogenesis induced by bacterial, viral, and parasitic infections (Hiraku, 2010; Kawanishi \& Hiraku, 2006; Kawanishi et al., 2006). The studies on 8-nitroguanine formation in relation to inflammation-related carcinogenesis are summarized in Table 3.

Infectious diseases

\begin{tabular}{|c|c|c|c|}
\hline Cause & Site of DNA damage & Species & References \\
\hline Helicobacter pyroli & Gastric epithelium & Human & (Ma et al., 2004) \\
\hline $\begin{array}{c}\text { Human papillomavirus } \\
(\mathrm{HPV})\end{array}$ & Cervical epithelium & Human & (Hiraku et al., 2007) \\
\hline Hepatitis $\mathrm{C}$ virus & Hepatocyte & Human & (Horiike et al., 2005) \\
\hline Epstein-Barr virus (EBV) & $\begin{array}{l}\text { Nasopharyngeal } \\
\text { epithelium } \\
\text { and tumor tissue }\end{array}$ & Human & (Ma et al., 2008) \\
\hline \multirow[t]{2}{*}{$\begin{array}{c}\text { Liver fluke } \\
\text { (Opisthorchis viverrini) }\end{array}$} & Bile duct epithelium & Hamster & $\begin{array}{c}\text { (Pinlaor et al., 2004a) } \\
\text { (Pinlaor et al., 2004b) } \\
\text { (Pinlaor et al., 2006) }\end{array}$ \\
\hline & Tumor tissue & Human & (Pinlaor et al., 2005) \\
\hline
\end{tabular}

Inflammatory diseases and conditions

\begin{tabular}{|c|c|c|c|}
\hline Cause & Site of DNA damage & Species & References \\
\hline Inflammatory bowel disease & Colon epithelium & Mouse & (Ding et al., 2005) \\
\hline Oral licken planus & Oral epithelium & Human & (Chaiyarit et al., 2005) \\
\hline Oral leukoplakia & Oral epithelium & Human & (Ma et al., 2006) \\
\hline $\begin{array}{c}\text { Soft tissue tumor } \\
\text { (Malignant histiocytoma) }\end{array}$ & Tumor tissue & Human & $\begin{array}{c}\text { (Hoki et al., 2007a) } \\
\text { (Hoki et al., 2007b) }\end{array}$ \\
\hline Asbestos & Bronchial epithelium & Mouse & (Hiraku et al., 2010) \\
\hline
\end{tabular}

Table 3. 8-Nitroguanine formation in humans and animals in relation to inflammationrelated carcinogenesis 
We found that 8-nitroguanine was formed in epithelial cells of intrahepatic bile duct using an animal model infected with the liver fluke Opisthorchis viverrini, endemic in northeastern Thailand (Pinlaor et al., 2004a; Pinlaor et al., 2004b; Pinlaor et al., 2003). Administration of the antiparasitic drug praziquantel and the antioxidant curcumin significantly reduced oxidative and nitrative DNA damage (Pinlaor et al., 2006; Prakobwong et al., 2011). We have also demonstrated that 8-nitroguanine was formed in the gastric gland epithelial cells from gastritis patients with Helicobacter pylori infection (Ma et al., 2004), in the hepatocytes of patients with chronic hepatitis C (Horiike et al., 2005) and in the nasopharyngeal epithelial cells and tumor tissues of patients infected with Epstein-Barr virus (EBV) (Ma et al., 2008). These results suggest that 8-nitroguanine is a promising biomarker providing an assessment of the risk of inflammation-mediated carcinogenesis at the precancerous stage. Moreover, in EBV-infected patients, the staining intensity of 8-nirtroguanine was significantly stronger in nasopharyngeal cancer cells than in epithelial cells of chronic nasopharyngitis patients, suggesting that 8-nitroguanine accumulates during the development of chronic inflammation to cancer (Ma et al., 2008). In addition, 8-nitroguanine formation was observed under inflammatory conditions independent of infection. This DNA lesion was seen in colon epithelial cells of a mouse model of inflammatory bowel disease (Ding et al., 2005), in oral epithelial cells of patients with oral premalignant lesions (Chaiyarit et al., 2005; Ma et al., 2006) and in bronchial epithelial cells of asbestos-exposed mice (Hiraku et al., 2010).

Several studies have raised a possibility that DNA damage is involved in tumor progression. In patients with inhrahepatic cholongiocarcinoma, oxidative and nitrative DNA damage in tumor and adjacent tissues was associated with tumor invasion (Pinlaor et al., 2005) 8-Nitroguanine staining was observed in tumor tissues of patients with malignant fibrous histiocytoma, a soft tissue tumor, which is proposed to be accompanied with inflammatory responses. The statistical analysis using the Kaplan-Meier method revealed that strong 8-nitroguanine formation was significantly associated with a poor prognosis of the patients (Hoki et al., 2007a). These findings indicate that this DNA lesion contributes to not only tumor initiation but also tumor progression and poor prognosis of cancer patients.

\subsection{Mechanism of inflammation-related carcinogenesis and the role of DNA damage}

On the basis of our previous studies, possible mechanism of inflammation-related carcinogenesis and tumor development via DNA damage is shown in Figure 4. Various infectious agents, including bacteria, viruses and parasites, inflammatory diseases and environmental factors can induce inflammatory responses and the production of ROS and RNS from inflammatory and epithelial cells. A wide variety of inflammatory cytokines mediate the activation of transcription factors, including NF- $\kappa B$ and STATs. NF- $\kappa B$ regulates the expression of a wide variety of inflammation-related molecules including iNOS (Karin, 2006; Kundu \& Surh, 2008) and participates in multiple steps of carcinogenesis (Karin, 2006; Pikarsky et al., 2004). RNS can induce the activation of NF-kB under certain circumstances (Janssen-Heininger et al., 2000). Therefore, reciprocal and positive regulation between RNS and NF- $\mathrm{KB}$ may lead to persistent inflammatory reactions and nitrative DNA damage, contributing to carcinogenesis. 


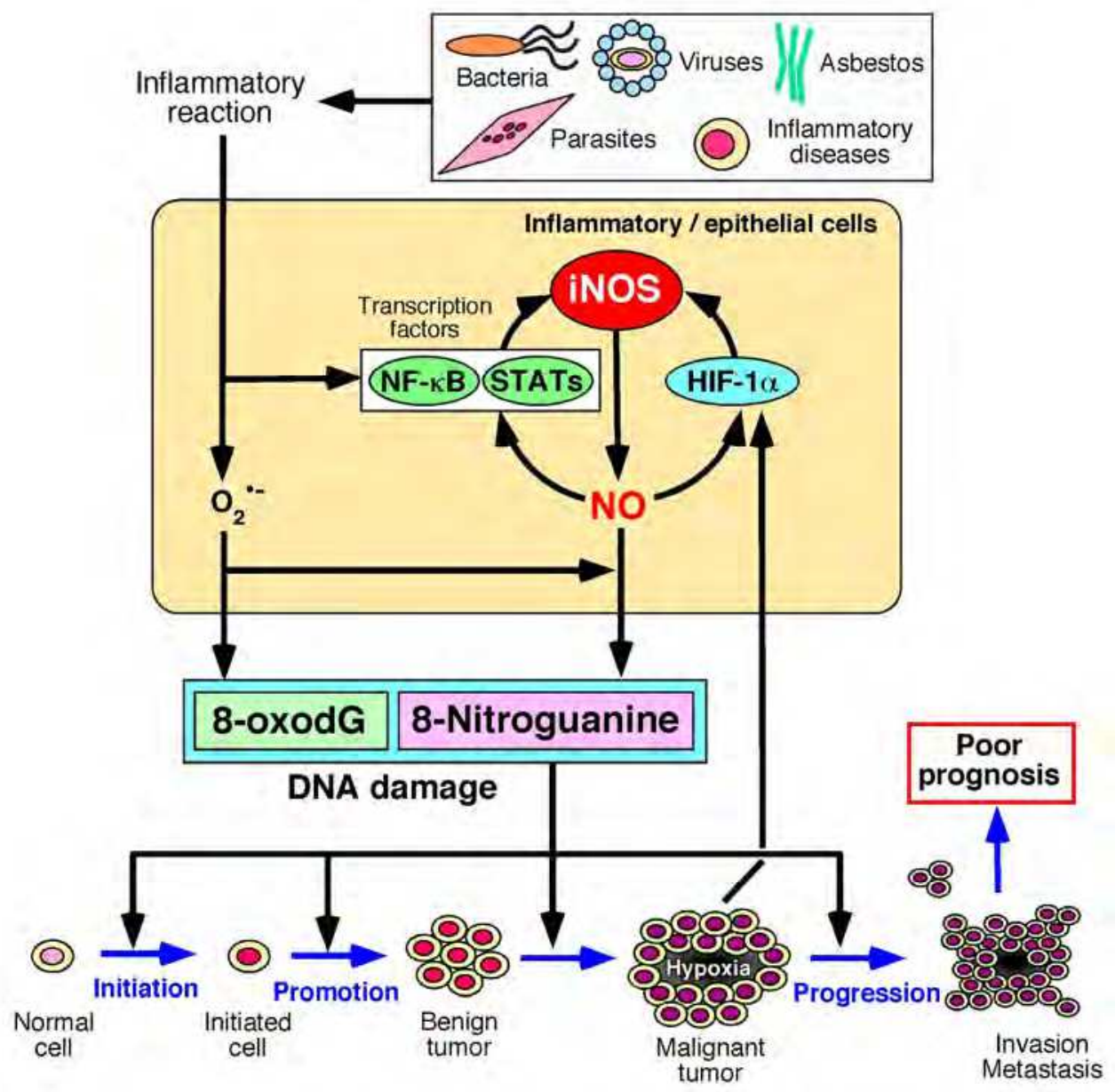

Fig. 4. Possible mechanism of inflammation-related carcinogenesis and tumor progression via 8-nitroguanine formation.

STAT1 and STAT3 are known to mediate the expression of iNOS (Lo et al., 2005; Tedeschi et al., 2003). STAT3 interacts with EGFR in the nucleus to form a complex, which mediates transcriptional activation of iNOS (Lo et al., 2005). Actually, phosphorylated STAT3 (active form) and EGFR were strongly expressed and colocalized in the nucleus of cancer cells of nasopharyngeal cancer patients (Ma et al., 2008). A recent study has demonstrated that excess ONOO- mediates the activation of JAK/STAT signalling pathway in experimental animals (H. Wang et al., 2009). These findings imply that a positive loop between STATs and iNOS may exist.

Hypoxia-inducible factor (HIF)- $1 \alpha$ is an oxygen-sensing transcription factor, which is upregulated in a hypoxic environment during tumor growth. HIF-1 $\alpha$ mediates the transcription of various genes, including iNOS and VEGF (Harris, 2002). An increase in 
iNOS-catalyzed NO production induces the accumulation and activation of HIF-1 $\alpha$ (Mateo et al., 2003; Thomas et al., 2004). HIF-1 $\alpha$ and 8-nitroguanine were colocalized and associated with poor prognosis of cancer patients (Hoki et al., 2007b). Therefore, reciprocal activation of HIF-1 $\alpha$ and iNOS may lead to persistent DNA damage in tumor tissues, contributing to poor prognosis of cancer patients. A recent study has demonstrated that IкB kinase (IKK)- $\beta$, involved in NF- $\mathrm{\kappa B}$ activation, is required for HIF- $1 \alpha$ protein accumulation under hypoxia in

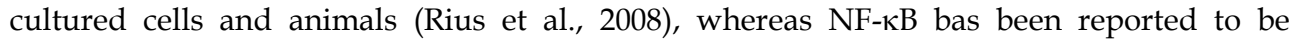
regulated under hypoxia in an HIF-1 $\alpha$-dependent manner (Walmsley et al., 2005). Thus, HIF- $1 \alpha$ and NF- $\kappa B$ may positively regulate each other and participate in tumor progression.

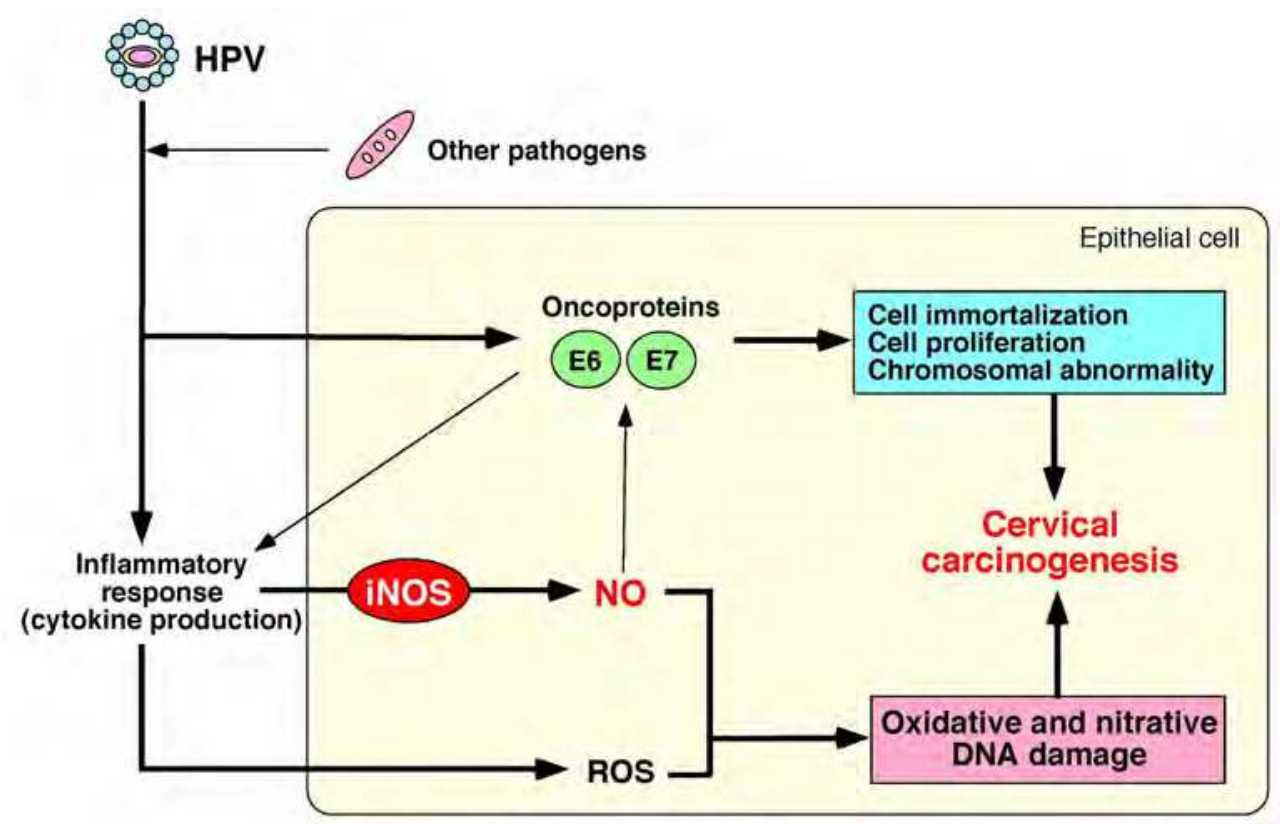

Fig. 5. Possible mechanism of HPV-induced cervical carcinogenesis mediated by chronic inflammation.

Collectively, molecular events mediated by various pathogens converge to nitrative stress, and resulting DNA damage contributes to the accumulation of genetic alterations in tissues throughout the carcinogenic process. In particular, 8-nitroguanine formation may participate in inflammation-related carcinogenesis as a common mechanism, regardless of etiology. Therefore, 8-nitroguanine could be used as a potential biomarker to evaluate the cancer risk and predict the prognosis of cancer patients. In addition, certain pathogens possess unique molecules mediating abnormal cell proliferation and survival, such as E6 and E7 proteins of HPV as described below. Therefore, 8-nitroguanine formation may contribute to carcinogenesis in cooperation with pathogen-specific molecular events.

A recent study has demonstrated that 8-nitro-cGMP, formed by the reaction of RNS with cGMP, regulates the redox-sensor signaling proteins, via S-guanylation of cysteine sulphydrils, and mediates an adaptive response against oxidative and nitrative stress (Sawa 
et al., 2007). S-Nitrosylated proteins, formed via reaction of thiols with NO or its reactive metabolites, possess cytoprotective properties (Ishima et al., 2007). In inflammation-related carcinogenesis, nitrated or nitrosylated molecules may participate in protection of initiated cells bearing genetic alterations due to oxidative and nitrative DNA damage, and contribute to tumor development.

\subsection{Mechanism of HPV-mediated cervical carcinogenesis via inflammatory reactions}

A possible mechanism of HPV-induced cervical carcinogenesis involving inflammatory reactions is shown in Figure 5. We have demonstrated that inflammation-mediated DNA lesions were formed in cervical tissues of CIN patients (Hiraku et al., 2007). To date, no evidence suggesting that HPV infection alone induces inflammatory states has been provided. Therefore, it is speculated that inflammatory reactions are derived from HPV infection and co-infection with other pathogens, although the precise mechanism remains to be clarified. DNA damage mediated by inflammatory reactions would play a substantial role in tumor initiation and also the following steps of carcinogenesis. In addition, HPV oncoproteins E6 and E7 mediate cell immortalization, dysregulation of cell proliferation and chromosomal abnormalities by interacting with numerous target proteins. The molecular events mediated by these oncoproteins may promote the proliferation and transformation of cells initiated by oxidative and nitrative DNA damage, and contribute to tumor promotion and progression.

In addition, several studies have demonstrated that HPV oncoproteins mediate inflammatory responses. The expression of E6 and E7 oncoproteins derived from highly carcinogenic HPV-16 enhanced the release of IL-1 $\alpha$ from cultures of normal cervical keratinocytes, and E7 proteins that strongly bound to RB protein (high risk types HPV-16 and HPV-18) induced more IL-1 $\alpha$ release than those that bound poorly (low-risk type HPV6) (Iglesias et al., 1998). A recent study has shown that E7 expression increased the promotor activity of COX-2 and the downstream molecule IL-32 in HPV-positive cervical cancer cell lines (Lee et al., 2011). IL-32 induces the expression of various inflammatory cytokines, including IL-1 $\beta$, IL-6, TNF- $\alpha$ and chemokines (S.H. Kim et al., 2005). IL-32 expression was detected in cervical tissues of patients with squamous cell carcinoma and increased with the tumor stage (Lee et al., 2011). Therefore, these HPV oncoproteins may participate in inflammatory responses in cervical tissues and contribute to carcinogenesis. In addition, a recent study has shown that NO treatment mediates the expression of E6 and E7 in cultured cells (Wei et al., 2009). A COX-2-selective inhibitor suppressed the expression of E7 in cultured cervical cancer cells (Lee et al., 2011). Inflammatory reactions may reciprocally mediate the expression of HPV oncoproteins, resulting in the persistence of inflammation-related DNA damage and dysregulated cell proliferation, contributing to tumor progression.

\section{Conclusion and future perspective}

Chronic infection and inflammation are known to contribute to a substantial part of environmental carcinogenesis. Cervical cancer is the second most common cancer among women, and HPV infection is involved in almost all cases. Recent epidemiological studies revealed that chronic inflammation participates in cervical carcinogenesis. Under 
inflammatory conditions, reactive oxygen and nitrogen species are generated, and resulting DNA damage may play an important role in carcinogenesis. We performed immunohistochemical analysis and demonstrated that 8-nitroguanine, a mutagenic DNA lesion formed during inflammation, was formed in cervical epithelial cells in CIN patients, and its immunoreactivity was significantly increased with CIN grades. The comparison of 8-nitroguanine formation and p16 expression revealed that 8-nitroguanine is more suitable to detect cervical lesions mediated by high-risk types of HPV. Taken together with this and previous studies, it is concluded that 8-nitroguanine can be used as a potential biomarker to evaluate the risk of inflammation-related carcinogenesis, including cervical carcinogenesis. In addition, HPV oncoproteins E6 and E7 are known to mediate cell immortalization, dysregulated cell proliferation and chromosomal instability. Several studies have suggested that these oncoproteins crosstalk with signalling pathways related to inflammatory responses. Therefore, oxidative and nitrative DNA damage mediated by inflammatory reactions and oncoprotein-mediated molecular events may cooperatively contribute to cervical carcinogenesis.

Establishment of methods for quantitative analysis of 8-nitroguanine in biological samples, such as blood and urine, would be useful for evaluation of the risk of inflammation-related carcinogenesis. 8-Nitroguanine formed in DNA is chemically unstable, and is likely to be released from DNA. Thus, this property may hamper the quantitative analysis. An attempt has been made to utilize free 8-nitroguanine in urine for quantitative analysis using highperformance liquid chromatography coupled with electrochemical detection and immunoaffinity purification (Sawa et al., 2006). 8-Nitroguanine has also been measured by liquid chromatography with mass spectrometry and glyoxal derivatization (Ishii et al., 2007).

Moreover, the development of therapeutics targeting inflammation-related molecules may contribute to prevention of cervical carcinogenesis and improvement of prognosis of cancer patients. Animal experiments demonstrated that iNOS inhibitors suppress inflammatory responses and effectively reduce inflammation-related carcinogenesis, although evidence has not yet been provided for their inhibitory effect on cervical carcinogenesis. ONO-1714, an iNOS-specific inhibitor, significantly decreased the degree of cholangitis and reduced the incidence of intrahepatic biliary tumors in bilioenterostomized hamsters (Mishima et al., 2009). Another iNOS inhibitor, $1400 \mathrm{~W}$, reduced tumorigenesis in the mammary glands of $\gamma$ irradiated mice treated with diethylstilbestrol (Inano \& Onoda, 2005). Moreover, administration of the antioxidant curcumin significantly reduced the incidence of liver fluke-induced carcinogenesis via suppression of oxidative and nitrative DNA damage (Prakobwong et al., 2011). To develop a strategy for prevention of HPV-mediated cervical cancer, further studies are needed to clarify the precise molecular mechanisms and the role of chronic inflammation.

\section{Acknowledgement}

The author is grateful to Dr. Tsutomu Tabata (Mie University Graduate School of Medicine, Japan) and Professor Ning Ma (Suzuka University of Medical Sciences, Japan) for clinical and technical advices, respectively. The author is also grateful to Professor Shosuke Kawanishi (Suzuka University of Medical Sciences), Professor Mariko Murata (Mie 
University Graduate School of Medicine) and all collaborators for the encouragement throughout this work. This work was supported by Grants-in-Aid for Scientific Research from the Ministry of Education, Culture, Sports, Science and Technology and the Ministry of Health, Labour and Welfare of Japan.

\section{References}

Akaike, T., Okamoto, S., Sawa, T., Yoshitake, J., Tamura, F., Ichimori, K., Miyazaki, K., Sasamoto, K. \& Maeda, H. (2003). 8-Nitroguanosine formation in viral pneumonia and its implication for pathogenesis. Proc. Natl. Acad. Sci. USA, Vol. 100, No. 2, pp. 685-690, ISSN 0027-8424

Balkwill, F. \& Mantovani, A. (2001). Inflammation and cancer: back to Virchow? Lancet, Vol. 357, No. 9255, pp. 539-545, ISSN 0140-6736

Bos, J.L. (1988). The ras gene family and human carcinogenesis. Mutat. Res., Vol. 195, No. 3, pp. 255-271, ISSN 0027-5107

Bosch, F.X., Lorincz, A., Munoz, N., Meijer, C.J. \& Shah, K.V. (2002). The causal relation between human papillomavirus and cervical cancer. J. Clin. Pathol., Vol. 55, No. 4, pp. 244-265, ISSN 0021-9746

Castle, P.E., Hillier, S.L., Rabe, L.K., Hildesheim, A., Herrero, R., Bratti, M.C., Sherman, M.E., Burk, R.D., Rodriguez, A.C., Alfaro, M., Hutchinson, M.L., Morales, J. \& Schiffman, M. (2001). An association of cervical inflammation with high-grade cervical neoplasia in women infected with oncogenic human papillomavirus (HPV). Cancer Epidemiol. Biomarkers Prev., Vol. 10, No. 10, pp. 1021-1027, ISSN 10559965

Castle, P.E. \& Giuliano, A.R. (2003). Chapter 4: Genital tract infections, cervical inflammation, and antioxidant nutrients-assessing their roles as human papillomavirus cofactors. J. Natl. Cancer Inst. Monogr., Vol. 31, pp. 29-34, ISSN 10526773

Chaiyarit, P., Ma, N., Hiraku, Y., Pinlaor, S., Yongvanit, P., Jintakanon, D., Murata, M., Oikawa, S. \& Kawanishi, S. (2005). Nitrative and oxidative DNA damage in oral lichen planus in relation to human oral carcinogenesis. Cancer Sci., Vol. 96, No. 9, pp. 553-559, ISSN 1347-9032

Chen, Y.C. \& Hunter, D.J. (2005). Molecular epidemiology of cancer. CA Cancer J. Clin., Vol. 55, No. 1, pp. 45-54, ISSN 0007-9235

Chun, K.S. \& Surh, Y.J. (2004). Signal transduction pathways regulating cyclooxygenase-2 expression: potential molecular targets for chemoprevention. Biochem. Pharmacol., Vol. 68, No. 6, pp. 1089-1100, ISSN 0006-2952

Coussens, L.M. \& Werb, Z. (2002). Inflammation and cancer. Nature, Vol. 420, No. 6917, pp. 860-867, ISSN 0028-0836

Darnell, G.A., Schroder, W.A., Antalis, T.M., Lambley, E., Major, L., Gardner, J., Birrell, G., Cid-Arregui, A. \& Suhrbier, A. (2007). Human papillomavirus E7 requires the protease calpain to degrade the retinoblastoma protein. J. Biol. Chem., Vol. 282, No. 52, pp. 37492-37500, ISSN 0021-9258

David, S.S., O'Shea, V.L. \& Kundu, S. (2007). Base-excision repair of oxidative DNA damage. Nature, Vol. 447, No. 7147, pp. 941-950, ISSN 0028-0836

Ding, X., Hiraku, Y., Ma, N., Kato, T., Saito, K., Nagahama, M., Semba, R., Kuribayashi, K. \& Kawanishi, S. (2005). Inducible nitric oxide synthase-dependent DNA damage in 
mouse model of inflammatory bowel disease. Cancer Sci., Vol. 96, No. 3, pp. 157163, ISSN 1347-9032

DiPaolo, J.A., Woodworth, C.D., Popescu, N.C., Notario, V. \& Doniger, J. (1989). Induction of human cervical squamous cell carcinoma by sequential transfection with human papillomavirus 16 DNA and viral Harvey ras. Oncogene, Vol. 4, No. 4, pp. 395-399, ISSN 0950-9232

Du, M.Q., Carmichael, P.L. \& Phillips, D.H. (1994). Induction of activating mutations in the human c-Ha-ras-1 proto-oncogene by oxygen free radicals. Mol. Carcinog., Vol. 11, No. 3, pp. 170-175, ISSN 0899-1987

Duensing, S., Lee, L.Y., Duensing, A., Basile, J., Piboonniyom, S., Gonzalez, S., Crum, C.P. \& Munger, K. (2000). The human papillomavirus type 16 E6 and E7 oncoproteins cooperate to induce mitotic defects and genomic instability by uncoupling centrosome duplication from the cell division cycle. Proc. Natl. Acad. Sci. USA, Vol. 97, No. 18, pp. 10002-10007, ISSN 0027-8424

Duensing, S. \& Munger, K. (2004). Mechanisms of genomic instability in human cancer: insights from studies with human papillomavirus oncoproteins. Int. J. Cancer, Vol. 109, No. 2, pp. 157-162, ISSN 0020-7136

Erhola, M., Toyokuni, S., Okada, K., Tanaka, T., Hiai, H., Ochi, H., Uchida, K., Osawa, T., Nieminen, M.M., Alho, H. \& Kellokumpu-Lehtinen, P. (1997). Biomarker evidence of DNA oxidation in lung cancer patients: association of urinary 8-hydroxy-2'deoxyguanosine excretion with radiotherapy, chemotherapy, and response to treatment. FEBS Lett., Vol. 409, No. 2, pp. 287-291, ISSN 0014-5793

Gillet, E., Meys, J.F., Verstraelen, H., Bosire, C., De Sutter, P., Temmerman, M. \& Broeck, D.V. (2011). Bacterial vaginosis is associated with uterine cervical human papillomavirus infection: a meta-analysis. BMC Infect. Dis., Vol. 11, No. pp. 10, ISSN 1471-2334

Gupta, R., Srinivasan, R., Nijhawan, R. \& Suri, V. (2010). Tissue transglutaminase 2 as a biomarker of cervical intraepithelial neoplasia (CIN) and its relationship to p16INK4A and nuclear factor кB expression. Virchows Arch., Vol. 456, No. 1, pp. 4551, ISSN 0945-6317

Harris, A.L. (2002). Hypoxia-a key regulatory factor in tumour growth. Nat. Rev. Cancer, Vol. 2, No. 1, pp. 38-47, ISSN 1474-175X

Hiraku, Y., Tabata, T., Ma, N., Murata, M., Ding, X. \& Kawanishi, S. (2007). Nitrative and oxidative DNA damage in cervical intraepithelial neoplasia associated with human papilloma virus infection. Cancer Sci., Vol. 98, No. 7, pp. 964-972, ISSN 1347-9032

Hiraku, Y. \& Kawanishi, S. (2009). Immunohistochemical analysis of 8-nitroguanine, a nitrative DNA lesion, in relation to inflammation-associated carcinogenesis. Methods Mol. Biol., Vol. 512, pp. 3-13, ISSN 1064-3745

Hiraku, Y. (2010). Formation of 8-nitroguanine, a nitrative DNA lesion, in inflammationrelated carcinogenesis and its significance. Environ. Health Prev. Med., Vol. 15, No. 2, pp. 63-72, ISSN 1342-078X

Hiraku, Y., Kawanishi, S., Ichinose, T. \& Murata, M. (2010). The role of iNOS-mediated DNA damage in infection- and asbestos-induced carcinogenesis. Ann. NY Acad. Sci., Vol. 1203, pp. 15-22, ISSN 0077-8923

Hoki, Y., Hiraku, Y., Ma, N., Murata, M., Matsumine, A., Nagahama, M., Shintani, K., Uchida, A. \& Kawanishi, S. (2007a). iNOS-dependent DNA damage in patients 
with malignant fibrous histiocytoma in relation to prognosis. Cancer Sci., Vol. 98, No. 2, pp. 163-168, ISSN 1347-9032

Hoki, Y., Murata, M., Hiraku, Y., Ma, N., Matsumine, A., Uchida, A. \& Kawanishi, S. (2007b). 8-Nitroguanine as a potential biomarker for progression of malignant fibrous histiocytoma, a model of inflammation-related cancer. Oncol. Rep., Vol. 18, No. 5, pp. 1165-1169, ISSN 1021-335X

Horiike, S., Kawanishi, S., Kaito, M., Ma, N., Tanaka, H., Fujita, N., Iwasa, M., Kobayashi, Y., Hiraku, Y., Oikawa, S., Murata, M., Wang, J., Semba, R., Watanabe, S. \& Adachi, Y. (2005). Accumulation of 8-nitroguanine in the liver of patients with chronic hepatitis C. J. Hepatol., Vol. 43, No. 3, pp. 403-410, ISSN 0168-8278

Hsu, I.C., Metcalf, R.A., Sun, T., Welsh, J.A., Wang, N.J. \& Harris, C.C. (1991). Mutational hotspot in the p53 gene in human hepatocellular carcinomas. Nature, Vol. 350, No. 6317, pp. 427-428, ISSN 0028-0836

Huh, K.W., DeMasi, J., Ogawa, H., Nakatani, Y., Howley, P.M. \& Munger, K. (2005). Association of the human papillomavirus type 16 E7 oncoprotein with the $600-\mathrm{kDa}$ retinoblastoma protein-associated factor, p600. Proc. Natl. Acad. Sci. USA, Vol. 102, No. 32, pp. 11492-11497, ISSN 0027-8424

Hussain, S.P., Hofseth, L.J. \& Harris, C.C. (2003). Radical causes of cancer. Nat. Rev. Cancer, Vol. 3, No. 4, pp. 276-285, ISSN 1474-175X

Hussain, S.P. \& Harris, C.C. (2007). Inflammation and cancer: an ancient link with novel potentials. Int. J. Cancer, Vol. 121, No. 11, pp. 2373-2380, ISSN 1097-0215

IARC, (2003). World Cancer Report, IARC Press, Lyon

IARC Working Group, (2007). IARC Monographs on the Evaluation of Carcinogenic Risks to Humans, Vol. 90, Human Papillomaviruses, IARC Press, Lyon

IARC Working Group, (2011). Human Papillomaviruses, In: IARC Monographs on the Evaluation of Carcinogenic Risks to Humans, Vol. 100B, A Review of Human Carcinogens, Part B: Biological Agents, pp. 261-319, IARC Press, Lyon

Iglesias, M., Yen, K., Gaiotti, D., Hildesheim, A., Stoler, M.H. \& Woodworth, C.D. (1998). Human papillomavirus type 16 E7 protein sensitizes cervical keratinocytes to apoptosis and release of interleukin-1 $\alpha$. Oncogene, Vol. 17, No. 10, pp. 1195-1205, ISSN 0950-9232

Inano, H. \& Onoda, M. (2005). Nitric oxide produced by inducible nitric oxide synthase is associated with mammary tumorigenesis in irradiated rats. Nitric Oxide, Vol. 12, No. 1, pp. 15-20, ISSN 1089-8603

Inoue, S. \& Kawanishi, S. (1995). Oxidative DNA damage induced by simultaneous generation of nitric oxide and superoxide. FEBS Lett., Vol. 371, No. 1, pp. 86-88, ISSN 0014-5793

Ishii, Y., Ogara, A., Okamura, T., Umemura, T., Nishikawa, A., Iwasaki, Y., Ito, R., Saito, K., Hirose, M. \& Nakazawa, H. (2007). Development of quantitative analysis of 8nitroguanine concomitant with 8-hydroxydeoxyguanosine formation by liquid chromatography with mass spectrometry and glyoxal derivatization. J. Pharm. Biomed. Anal., Vol. 43, No. 5, pp. 1737-1743, ISSN 0731-7085

Ishima, Y., Sawa, T., Kragh-Hansen, U., Miyamoto, Y., Matsushita, S., Akaike, T. \& Otagiri, M. (2007). S-Nitrosylation of human variant albumin liprizzi (R410C) confers potent antibacterial and cytoprotective properties. J. Pharmacol. Exp. Ther., Vol. 320, No. 3, pp. 969-977, ISSN 0022-3565 
Janssen-Heininger, Y.M., Poynter, M.E. \& Baeuerle, P.A. (2000). Recent advances towards understanding redox mechanisms in the activation of nuclear factor $\kappa \mathrm{B}$. Free Radic. Biol. Med., Vol. 28, No. 9, pp. 1317-1327, ISSN 0891-5849

Juedes, M.J. \& Wogan, G.N. (1996). Peroxynitrite-induced mutation spectra of pSP189 following replication in bacteria and in human cells. Mutat. Res., Vol. 349, No. 1, pp. 51-61, ISSN 0027-5107

Karin, M. (2006). Nuclear factor- $\kappa B$ in cancer development and progression. Nature, Vol. 441, No. 7092, pp. 431-436, ISSN 1476-4687

Kawanishi, S., Hiraku, Y. \& Oikawa, S. (2001). Mechanism of guanine-specific DNA damage by oxidative stress and its role in carcinogenesis and aging. Mutat. Res., Vol. 488, No. 1, pp. 65-76, ISSN 0027-5107

Kawanishi, S. \& Hiraku, Y. (2006). Oxidative and nitrative DNA damage as biomarker for carcinogenesis with special reference to inflammation. Antioxid. Redox Signal., Vol. 8, No. 5-6, pp. 1047-1058, ISSN 1523-0864

Kawanishi, S., Hiraku, Y., Pinlaor, S. \& Ma, N. (2006). Oxidative and nitrative DNA damage in animals and patients with inflammatory diseases in relation to inflammationrelated carcinogenesis. Biol. Chem., Vol. 387, No. 4, pp. 365-372, ISSN 1431-6730

Kemp, T.J., Hildesheim, A., Garcia-Pineres, A., Williams, M.C., Shearer, G.M., Rodriguez, A.C., Schiffman, M., Burk, R., Freer, E., Bonilla, J., Herrero, R. \& Pinto, L.A. (2010). Elevated systemic levels of inflammatory cytokines in older women with persistent cervical human papillomavirus infection. Cancer Epidemiol. Biomarkers Prev., Vol. 19, No. 8, pp. 1954-1959, ISSN 1055-9965

Kessis, T.D., Slebos, R.J., Nelson, W.G., Kastan, M.B., Plunkett, B.S., Han, S.M., Lorincz, A.T., Hedrick, L. \& Cho, K.R. (1993). Human papillomavirus 16 E6 expression disrupts the p53-mediated cellular response to DNA damage. Proc. Natl. Acad. Sci. USA, Vol. 90, No. 9, pp. 3988-3992, ISSN 0027-8424

Khleif, S.N., DeGregori, J., Yee, C.L., Otterson, G.A., Kaye, F.J., Nevins, J.R. \& Howley, P.M. (1996). Inhibition of cyclin D-CDK4/CDK6 activity is associated with an E2Fmediated induction of cyclin kinase inhibitor activity. Proc. Natl. Acad. Sci. USA, Vol. 93, No. 9, pp. 4350-4354, ISSN 0027-8424

Kim, G.E., Kim, Y.B., Cho, N.H., Chung, H.C., Pyo, H.R., Lee, J.D., Park, T.K., Koom, W.S., Chun, M. \& Suh, C.O. (2004). Synchronous coexpression of epidermal growth factor receptor and cyclooxygenase- 2 in carcinomas of the uterine cervix: a potential predictor of poor survival. Clin. Cancer Res., Vol. 10, No. 4, pp. 1366-1374, ISSN 1078-0432

Kim, M.Y., Dong, M., Dedon, P.C. \& Wogan, G.N. (2005). Effects of peroxynitrite dose and dose rate on DNA damage and mutation in the supF shuttle vector. Chem. Res. Toxicol., Vol. 18, No. 1, pp. 76-86, ISSN 0893-228X

Kim, S.H., Han, S.Y., Azam, T., Yoon, D.Y. \& Dinarello, C.A. (2005). Interleukin-32: a cytokine and inducer of TNFa. Immunity, Vol. 22, No. 1, pp. 131-142, ISSN 10747613

Klaes, R., Friedrich, T., Spitkovsky, D., Ridder, R., Rudy, W., Petry, U., Dallenbach-Hellweg, G., Schmidt, D. \& von Knebel Doeberitz, M. (2001). Overexpression of p16(INK4A) as a specific marker for dysplastic and neoplastic epithelial cells of the cervix uteri. Int. J. Cancer, Vol. 92, No. 2, pp. 276-284, ISSN 0020-7136 
Kovacic, M.B., Katki, H.A., Kreimer, A.R. \& Sherman, M.E. (2008). Epidemiologic analysis of histologic cervical inflammation: relationship to human papillomavirus infections. Hum. Pathol., Vol. 39, No. 7, pp. 1088-1095, ISSN 0046-8177

Kulkarni, S., Rader, J.S., Zhang, F., Liapis, H., Koki, A.T., Masferrer, J.L., Subbaramaiah, K. \& Dannenberg, A.J. (2001). Cyclooxygenase-2 is overexpressed in human cervical cancer. Clin. Cancer Res., Vol. 7, No. 2, pp. 429-434, ISSN 1078-0432

Kundu, J.K. \& Surh, Y.J. (2008). Inflammation: gearing the journey to cancer. Mutat. Res., Vol. 659, No. 1-2, pp. 15-30, ISSN 0027-5107

Lee, S., Kim, J.H., Kim, H., Kang, J.W., Kim, S.H., Yang, Y., Kim, J., Park, J., Park, S., Hong, J. \& Yoon, D.Y. (2011). Activation of the interleukin-32 pro-inflammatory pathway in response to human papillomavirus infection and over-expression of interleukin-32 controls the expression of the human papillomavirus oncogene. Immunology, Vol. 132, No. 3, pp. 410-420, ISSN 0019-2805

Lo, H.W., Hsu, S.C., Ali-Seyed, M., Gunduz, M., Xia, W., Wei, Y., Bartholomeusz, G., Shih, J.Y. \& Hung, M.C. (2005). Nuclear interaction of EGFR and STAT3 in the activation of the iNOS/NO pathway. Cancer Cell, Vol. 7, No. 6, pp. 575-589, ISSN 1535-6108

Loeb, L.A. \& Preston, B.D. (1986). Mutagenesis by apurinic/apyrimidinic sites. Annu. Rev. Genet., Vol. 20, pp. 201-230, ISSN 0066-4197

Ma, N., Adachi, Y., Hiraku, Y., Horiki, N., Horiike, S., Imoto, I., Pinlaor, S., Murata, M., Semba, R. \& Kawanishi, S. (2004). Accumulation of 8-nitroguanine in human gastric epithelium induced by Helicobacter pylori infection. Biochem. Biophys. Res. Commun., Vol. 319, No. 2, pp. 506-510, ISSN 0006-291X

Ma, N., Tagawa, T., Hiraku, Y., Murata, M., Ding, X. \& Kawanishi, S. (2006). 8-Nitroguanine formation in oral leukoplakia, a premalignant lesion. Nitric Oxide, Vol. 14, No. 2, pp. 137-143, ISSN 1089-8603

Ma, N., Kawanishi, M., Hiraku, Y., Murata, M., Huang, G.W., Huang, Y., Luo, D.Z., Mo, W.G., Fukui, Y. \& Kawanishi, S. (2008). Reactive nitrogen species-dependent DNA damage in EBV-associated nasopharyngeal carcinoma: The relation to STAT3 activation and EGFR expression. Int. J. Cancer, Vol. 122, No. 11, pp. 2517-2525, ISSN 1097-0215

Mateo, J., Garcia-Lecea, M., Cadenas, S., Hernandez, C. \& Moncada, S. (2003). Regulation of hypoxia-inducible factor- $1 \alpha$ by nitric oxide through mitochondria-dependent and independent pathways. Biochem. J., Vol. 376(Pt 2), pp. 537-544, ISSN 1470-8728

Mishima, T., Tajima, Y., Kuroki, T., Kosaka, T., Adachi, T., Kitasato, A., Tsuneoka, N., Kitajima, T. \& Kanematsu, T. (2009). Chemopreventative effect of an inducible nitric oxide synthase inhibitor, ONO-1714, on inflammation-associated biliary carcinogenesis in hamsters. Carcinogenesis, Vol. 30, No. 10, pp. 1763-1767, ISSN 0143-3334

Munoz, N., Bosch, F.X., de Sanjose, S., Herrero, R., Castellsague, X., Shah, K.V., Snijders, P.J. \& Meijer, C.J. (2003). Epidemiologic classification of human papillomavirus types associated with cervical cancer. N. Engl. J. Med., Vol. 348, No. 6, pp. 518-527, ISSN 1533-4406

Nair, A., Venkatraman, M., Maliekal, T.T., Nair, B. \& Karunagaran, D. (2003). NF-кB is constitutively activated in high-grade squamous intraepithelial lesions and squamous cell carcinomas of the human uterine cervix. Oncogene, Vol. 22, No. 1, pp. 50-58, ISSN 0950-9232 
Nair, J., Gansauge, F., Beger, H., Dolara, P., Winde, G. \& Bartsch, H. (2006). Increased etheno-DNA adducts in affected tissues of patients suffering from Crohn's disease, ulcerative colitis, and chronic pancreatitis. Antioxid. Redox Signal., Vol. 8, No. 5-6, pp. 1003-1010, ISSN 1523-0864

Ohshima, H., Tatemichi, M. \& Sawa, T. (2003). Chemical basis of inflammation-induced carcinogenesis. Arch. Biochem. Biophys., Vol. 417, No. 1, pp. 3-11, ISSN 0003-9861

Pikarsky, E., Porat, R.M., Stein, I., Abramovitch, R., Amit, S., Kasem, S., Gutkovich-Pyest, E., Urieli-Shoval, S., Galun, E. \& Ben-Neriah, Y. (2004). NF-кB functions as a tumour promoter in inflammation-associated cancer. Nature, Vol. 431, No. 7007, pp. 461466, ISSN 1476-4687

Pinlaor, S., Yongvanit, P., Hiraku, Y., Ma, N., Semba, R., Oikawa, S., Murata, M., Sripa, B., Sithithaworn, P. \& Kawanishi, S. (2003). 8-Nitroguanine formation in the liver of hamsters infected with Opisthorchis viverrini. Biochem. Biophys. Res. Commun., Vol. 309, No. 3, pp. 567-571, ISSN 0006-291X

Pinlaor, S., Hiraku, Y., Ma, N., Yongvanit, P., Semba, R., Oikawa, S., Murata, M., Sripa, B., Sithithaworn, P. \& Kawanishi, S. (2004a). Mechanism of NO-mediated oxidative and nitrative DNA damage in hamsters infected with Opisthorchis viverrini: a model of inflammation-mediated carcinogenesis. Nitric Oxide, Vol. 11, No. 2, pp. 175-183, ISSN 1089-8603

Pinlaor, S., Ma, N., Hiraku, Y., Yongvanit, P., Semba, R., Oikawa, S., Murata, M., Sripa, B., Sithithaworn, P. \& Kawanishi, S. (2004b). Repeated infection with Opisthorchis viverrini induces accumulation of 8-nitroguanine and 8-oxo-7,8-dihydro-2'deoxyguanine in the bile duct of hamsters via inducible nitric oxide synthase. Carcinogenesis, Vol. 25, No. 8, pp. 1535-1542, ISSN 0143-3334

Pinlaor, S., Sripa, B., Ma, N., Hiraku, Y., Yongvanit, P., Wongkham, S., Pairojkul, C., Bhudhisawasdi, V., Oikawa, S., Murata, M., Semba, R. \& Kawanishi, S. (2005). Nitrative and oxidative DNA damage in intrahepatic cholangiocarcinoma patients in relation to tumor invasion. World J. Gastroenterol., Vol. 11, No. 30, pp. 4644-4649, ISSN 1007-9327

Pinlaor, S., Hiraku, Y., Yongvanit, P., Tada-Oikawa, S., Ma, N., Pinlaor, P., Sithithaworn, P., Sripa, B., Murata, M., Oikawa, S. \& Kawanishi, S. (2006). iNOS-dependent DNA damage via NF-кB expression in hamsters infected with Opisthorchis viverrini and its suppression by the antihelminthic drug praziquantel. Int. J. Cancer, Vol. 119, No. 5, pp. 1067-1072, ISSN 0020-7136

Prakobwong, S., Khoontawad, J., Yongvanit, P., Pairojkul, C., Hiraku, Y., Sithithaworn, P., Pinlaor, P., Aggarwal, B.B. \& Pinlaor, S. (2011). Curcumin decreases cholangiocarcinogenesis in hamsters by suppressing inflammation-mediated molecular events related to multistep carcinogenesis. Int. J. Cancer, Vol. 129, No. 1, pp. 88-100, ISSN 0020-7136

Rius, J., Guma, M., Schachtrup, C., Akassoglou, K., Zinkernagel, A.S., Nizet, V., Johnson, R.S., Haddad, G.G. \& Karin, M. (2008). NF-кB links innate immunity to the hypoxic response through transcriptional regulation of HIF-1 $\alpha$. Nature, Vol. 453, No. 7196, pp. 807-811, ISSN 1476-4687

Roeters, A.M., Boon, M.E., van Haaften, M., Vernooij, F., Bontekoe, T.R. \& Heintz, A.P. (2010). Inflammatory events as detected in cervical smears and squamous intraepithelial lesions. Diagn. Cytopathol., Vol. 38, No. 2, pp. 85-93, ISSN 1097-0339 
Romano, G., Sgambato, A., Mancini, R., Capelli, G., Giovagnoli, M.R., Flamini, G., Boninsegna, A., Vecchione, A. \& Cittadini, A. (2000). 8-Hydroxy-2'-deoxyguanosine in cervical cells: correlation with grade of dysplasia and human papillomavirus infection. Carcinogenesis, Vol. 21, No. 6, pp. 1143-1147, ISSN 0143-3334

Sano, T., Oyama, T., Kashiwabara, K., Fukuda, T. \& Nakajima, T. (1998). Expression status of p16 protein is associated with human papillomavirus oncogenic potential in cervical and genital lesions. Am. J. Pathol., Vol. 153, No. 6, pp. 1741-1748, ISSN 00029440

Sawa, T., Tatemichi, M., Akaike, T., Barbin, A. \& Ohshima, H. (2006). Analysis of urinary 8nitroguanine, a marker of nitrative nucleic acid damage, by high-performance liquid chromatography-electrochemical detection coupled with immunoaffinity purification: Association with cigarette smoking. Free Radic. Biol. Med., Vol. 40, No. 4, pp. 711-720, ISSN 0891-5849

Sawa, T., Zaki, M.H., Okamoto, T., Akuta, T., Tokutomi, Y., Kim-Mitsuyama, S., Ihara, H., Kobayashi, A., Yamamoto, M., Fujii, S., Arimoto, H. \& Akaike, T. (2007). Protein Sguanylation by the biological signal 8-nitroguanosine 3',5'-cyclic monophosphate. Nat. Chem. Biol., Vol. 3, No. 11, pp. 727-735, ISSN 1552-4450

Schroer, N., Pahne, J., Walch, B., Wickenhauser, C. \& Smola, S. (2011). Molecular pathobiology of human cervical high-grade lesions: paracrine STAT3 activation in tumor-instructed myeloid cells drives local MMP-9 expression. Cancer Res., Vol. 71, No. 1, pp. 87-97, ISSN 0008-5472

Shibutani, S., Takeshita, M. \& Grollman, A.P. (1991). Insertion of specific bases during DNA synthesis past the oxidation-damaged base 8-oxodG. Nature, Vol. 349, No. 6308, pp. 431-434, ISSN 0028-0836

Sisk, E.A. \& Robertson, E.S. (2002). Clinical implications of human papillomavirus infection. Front. Biosci., Vol. 7, pp. e77-84, ISSN 1093-4715

Smith, J.S., Herrero, R., Bosetti, C., Munoz, N., Bosch, F.X., Eluf-Neto, J., Castellsague, X., Meijer, C.J., Van den Brule, A.J., Franceschi, S. \& Ashley, R. (2002a). Herpes simplex virus-2 as a human papillomavirus cofactor in the etiology of invasive cervical cancer. J. Natl. Cancer Inst., Vol. 94, No. 21, pp. 1604-1613, ISSN 0027-8874

Smith, J.S., Munoz, N., Herrero, R., Eluf-Neto, J., Ngelangel, C., Franceschi, S., Bosch, F.X., Walboomers, J.M. \& Peeling, R.W. (2002b). Evidence for Chlamydia trachomatis as a human papillomavirus cofactor in the etiology of invasive cervical cancer in Brazil and the Philippines. J. Infect. Dis., Vol. 185, No. 3, pp. 324-331, ISSN 0022-1899

Song, S., Gulliver, G.A. \& Lambert, P.F. (1998). Human papillomavirus type 16 E6 and E7 oncogenes abrogate radiation-induced DNA damage responses in vivo through p53-dependent and p53-independent pathways. Proc. Natl. Acad. Sci. USA, Vol. 95, No. 5, pp. 2290-2295, ISSN 0027-8424

Suzuki, N., Yasui, M., Geacintov, N.E., Shafirovich, V. \& Shibutani, S. (2005). Miscoding events during DNA synthesis past the nitration-damaged base 8-nitroguanine. Biochemistry, Vol. 44, No. 25, pp. 9238-9245, ISSN 0006-2960

Tagesson, C., Kallberg, M., Klintenberg, C. \& Starkhammar, H. (1995). Determination of urinary 8-hydroxydeoxyguanosine by automated coupled-column high performance liquid chromatography: a powerful technique for assaying in vivo oxidative DNA damage in cancer patients. Eur. J. Cancer, Vol. 31A, No. 6, pp. 934940, ISSN 0959-8049 
Takahashi, T., Nau, M.M., Chiba, I., Birrer, M.J., Rosenberg, R.K., Vinocour, M., Levitt, M., Pass, H., Gazdar, A.F. \& Minna, J.D. (1989). p53: a frequent target for genetic abnormalities in lung cancer. Science, Vol. 246, No. 4929, pp. 491-494, ISSN 00368075

Tazawa, H., Okada, F., Kobayashi, T., Tada, M., Mori, Y., Une, Y., Sendo, F., Kobayashi, M. \& Hosokawa, M. (2003). Infiltration of neutrophils is required for acquisition of metastatic phenotype of benign murine fibrosarcoma cells: implication of inflammation-associated carcinogenesis and tumor progression. Am. J. Pathol., Vol. 163, No. 6, pp. 2221-2232, ISSN 0002-9440

Tedeschi, E., Menegazzi, M., Margotto, D., Suzuki, H., Forstermann, U. \& Kleinert, H. (2003). Anti-inflammatory actions of St. John's wort: inhibition of human inducible nitricoxide synthase expression by down-regulating signal transducer and activator of transcription-1 $\alpha$ (STAT-1 $\alpha$ ) activation. J. Pharmacol. Exp. Ther., Vol. 307, No. 1, pp. 254-261, ISSN 0022-3565

Thanan, R., Murata, M., Pinlaor, S., Sithithaworn, P., Khuntikeo, N., Tangkanakul, W., Hiraku, Y., Oikawa, S., Yongvanit, P. \& Kawanishi, S. (2008). Urinary 8-oxo-7,8dihydro-2'-deoxyguanosine in patients with parasite infection and effect of antiparasitic drug in relation to cholangiocarcinogenesis. Cancer Epidemiol. Biomarkers Prev., Vol. 17, No. 3, pp. 518-524, ISSN 1055-9965

Thomas, D.D., Espey, M.G., Ridnour, L.A., Hofseth, L.J., Mancardi, D., Harris, C.C. \& Wink, D.A. (2004). Hypoxic inducible factor $1 \alpha$, extracellular signal-regulated kinase, and p53 are regulated by distinct threshold concentrations of nitric oxide. Proc. Natl. Acad. Sci. USA, Vol. 101, No. 24, pp. 8894-8899, ISSN 0027-8424

Tindle, R.W. (2002). Immune evasion in human papillomavirus-associated cervical cancer. Nat. Rev. Cancer, Vol. 2, No. 1, pp. 59-65, ISSN 1474-175X

Unfried, K., Schurkes, C. \& Abel, J. (2002). Distinct spectrum of mutations induced by crocidolite asbestos: clue for 8-hydroxydeoxyguanosine-dependent mutagenesis in vivo. Cancer Res., Vol. 62, No. 1, pp. 99-104, ISSN 0008-5472

von Knebel Doeberitz, M. (2002). New markers for cervical dysplasia to visualise the genomic chaos created by aberrant oncogenic papillomavirus infections. Eur. J. Cancer, Vol. 38, No. 17, pp. 2229-2242, ISSN 0959-8049

Walmsley, S.R., Print, C., Farahi, N., Peyssonnaux, C., Johnson, R.S., Cramer, T., Sobolewski, A., Condliffe, A.M., Cowburn, A.S., Johnson, N. \& Chilvers, E.R. (2005). Hypoxiainduced neutrophil survival is mediated by HIF-1 $\alpha$-dependent NF- $\kappa B$ activity. J. Exp. Med., Vol. 201, No. 1, pp. 105-115, ISSN 0022-1007

Wang, H., Li, Y., Liu, H., Liu, S., Liu, Q., Wang, X.M., Shi, Y. \& Duan, H. (2009). Peroxynitrite mediates glomerular lesion of diabetic rat via JAK/STAT signaling pathway. J. Endocrinol. Invest., Vol. 32, No. 10, pp. 844-851, ISSN 0391-4097

Wang, J.L., Zheng, B.Y., Li, X.D., Angstrom, T., Lindstrom, M.S. \& Wallin, K.L. (2004). Predictive significance of the alterations of p16INK4A, p14ARF, p53, and proliferating cell nuclear antigen expression in the progression of cervical cancer. Clin. Cancer Res., Vol. 10, No. 7, pp. 2407-2414, ISSN 1078-0432

Warner, T.D. \& Mitchell, J.A. (2004). Cyclooxygenases: new forms, new inhibitors, and lessons from the clinic. FASEB J., Vol. 18, No. 7, pp. 790-804, ISSN 1530-6860

Wei, L., Gravitt, P.E., Song, H., Maldonado, A.M. \& Ozbun, M.A. (2009). Nitric oxide induces early viral transcription coincident with increased DNA damage and 
mutation rates in human papillomavirus-infected cells. Cancer Res., Vol. 69, No. 11, pp. 4878-4884, ISSN 0008-5472

Williams, C.S., Tsujii, M., Reese, J., Dey, S.K. \& DuBois, R.N. (2000). Host cyclooxygenase-2 modulates carcinoma growth. J. Clin. Invest., Vol. 105, No. 11, pp. 1589-1594, ISSN 0021-9738

Wiseman, H. \& Halliwell, B. (1996). Damage to DNA by reactive oxygen and nitrogen species: role in inflammatory disease and progression to cancer. Biochem. J., Vol. 313 (Pt 1), pp. 17-29, ISSN 0264-6021

Wu, X., Takenaka, K., Sonoda, E., Hochegger, H., Kawanishi, S., Kawamoto, T., Takeda, S. \& Yamazoe, M. (2006). Critical roles for polymerase $\zeta$ in cellular tolerance to nitric oxide-induced DNA damage. Cancer Res., Vol. 66, No. 2, pp. 748-754, ISSN 00085472

Xu, M., Luo, W., Elzi, D.J., Grandori, C. \& Galloway, D.A. (2008). NFX1 interacts with $\mathrm{mSin} 3 \mathrm{~A} /$ histone deacetylase to repress hTERT transcription in keratinocytes. Mol. Cell Biol., Vol. 28, No. 15, pp. 4819-4828, ISSN 0270-7306

Yermilov, V., Rubio, J., Becchi, M., Friesen, M.D., Pignatelli, B. \& Ohshima, H. (1995a). Formation of 8-nitroguanine by the reaction of guanine with peroxynitrite in vitro. Carcinogenesis, Vol. 16, No. 9, pp. 2045-2050, ISSN 0143-3334

Yermilov, V., Rubio, J. \& Ohshima, H. (1995b). Formation of 8-nitroguanine in DNA treated with peroxynitrite in vitro and its rapid removal from DNA by depurination. FEBS Lett., Vol. 376, No. 3, pp. 207-210, ISSN 0014-5793

Yugawa, T. \& Kiyono, T. (2009). Molecular mechanisms of cervical carcinogenesis by highrisk human papillomaviruses: novel functions of E6 and E7 oncoproteins. Rev. Med. Virol., Vol. 19, No. 2, pp. 97-113, ISSN 1052-9276 


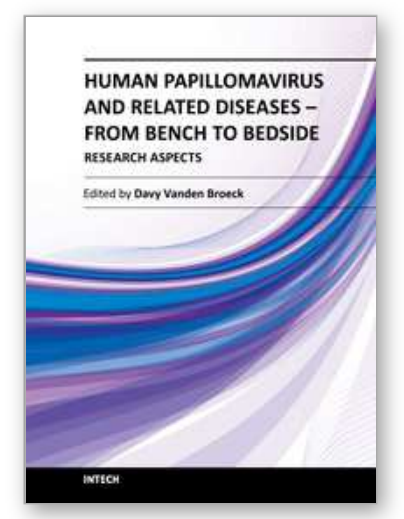

\author{
Human Papillomavirus and Related Diseases - From Bench to \\ Bedside - Research aspects \\ Edited by Dr. Davy Vanden Broeck
}

ISBN 978-953-307-855-7

Hard cover, 406 pages

Publisher InTech

Published online 25, January, 2012

Published in print edition January, 2012

Cervical cancer is the second most prevalent cancer among women worldwide, and infection with Human Papilloma Virus (HPV) has been identified as the causal agent for this condition. The natural history of cervical cancer is characterized by slow disease progression, rendering the condition, in essence, preventable and even treatable when diagnosed in early stages. Pap smear and the recently introduced prophylactic vaccines are the most prominent prevention options, but despite the availability of these primary and secondary screening tools, the global burden of disease is unfortunately still very high. This book will focus on epidemiological and fundamental research aspects in the area of HPV, and it will update those working in this fast-progressing field with the latest information.

\title{
How to reference
}

In order to correctly reference this scholarly work, feel free to copy and paste the following:

Yusuke Hiraku (2012). Role of Chronic Inflammation and Resulting DNA Damage in Cervical Carcinogenesis Induced by Human Papillomavirus, Human Papillomavirus and Related Diseases - From Bench to Bedside Research aspects, Dr. Davy Vanden Broeck (Ed.), ISBN: 978-953-307-855-7, InTech, Available from: http://www.intechopen.com/books/human-papillomavirus-and-related-diseases-from-bench-to-bedsideresearch-aspects/role-of-chronic-inflammation-and-resulting-dna-damage-in-cervical-carcinogenesis-inducedby-human-pa

\section{INTECH}

open science | open minds

\section{InTech Europe}

University Campus STeP Ri

Slavka Krautzeka 83/A

51000 Rijeka, Croatia

Phone: +385 (51) 770447

Fax: +385 (51) 686166

www.intechopen.com

\section{InTech China}

Unit 405, Office Block, Hotel Equatorial Shanghai

No.65, Yan An Road (West), Shanghai, 200040, China

中国上海市延安西路65号上海国际贵都大饭店办公楼 405 单元

Phone: +86-21-62489820

Fax: $+86-21-62489821$ 
(C) 2012 The Author(s). Licensee IntechOpen. This is an open access article distributed under the terms of the Creative Commons Attribution 3.0 License, which permits unrestricted use, distribution, and reproduction in any medium, provided the original work is properly cited. 